\title{
'Doing' Social Work: Critical Considerations on Theory and Practice in Social Work
}

\author{
Marcus Herz \\ Thomas Johansson
}

\begin{abstract}
Social work is a multi-dimensional and contradictory field of practice, which often leads to theoretical confusion. Another tendency within social work today is the development of an evidence-based practice. This kind of social engineering, together with the theoretical confusion, might lead to the reproduction and strengthening of dominant discourses and perspectives. Pointing out the need for critical theory to transgress and resist hegemonic practices, the article aims to present ideas on how to theoretically position social work practice within a framework of critical theory. The question is how to combine an ambition to develop suitable methods and to anchor social work in a sound social-scientific context with critical theories concerning, for instance, gender, ethnicity, and class. It is suggested that a movement towards a more deconstructive and reflexive mode of thinking and practicing social work, 'doing social work', would enable the field to become more ethical and reflexive.
\end{abstract}

Keywords: Critical theory, doing gender, evidence, reflexivity

\section{INTRODUCTION}

Feminists and postcolonial theorists have formulated a massive critique of social work, accusing it both of being gender blind and of neglecting critical perspectives on power, ethnicity, and the social situation of immigrants (Herz \& Johansson, 2011). An increasing number of academic studies on these issues show that social work practices often are influenced by stereotypical views on gender and ethnicity (Burck \& Gwyn, 1995; Dominelli, 2008; Sue, 2006).

Although a critical tradition in social work has a long history, often known as critical social work, it has often focused mainly on creating awareness among, and strengthening, clients (Fook, 2002) or sometimes on how to work directly with clients (Englar-Carlson \& Shepard, 2005; White, 2004). In order to be able to meet the challenges stated above, our framework is directed toward producing change in the social worker's thinking, and to seek a possible convergence between critical social work and evidence-based practice (EBP). What we are suggesting is a development towards a meta-reflexive way of thinking, where social workers examine their own work. This differs from other critical approaches which often seem to completely seek to reject and replace EBP (Fook \& Gardner, 2007; Pease \& Fook, 1999). Another reason for this need is the appearance of new emerging challenges.

One such emerging challenge is the strong tendency within social work to develop evidence-based and scientific methods, methodologies, and approaches to social problems. This kind of social engineering often leads to an ambition to promote certain methods and methodologies singled out as superior, and to discard 'unscientific' methods. While this may very well be a necessary way to proceed in a field of practice and research populated by a diversity of methods and approaches,

Marcus Herz is a social work Ph.D. student in the Department for Law, Psychology, and Social Work at Örebro

University in Örebro, Sweden. Thomas Johansson, Ph.D., is a Professor of Education in the Department of Education, Communication, and Learning at Göteborg University in Göteborg, Sweden.

Copyright (C) 2012 Advances in Social Work Vol. 13 No. 3 (Fall 2012), 527-540 
there is also a risk that critical methods and alternative ways of working with social problems are thrown out with the bathwater. As we know, social engineering and critical theory are not compatible perspectives - rather the opposite (Marcuse, 1964). Whereas social engineering often leads to the reproduction and strengthening of dominant discourses and perspectives, the ambition of critical theory is to transgress and resist hegemonic practices and ideologies.

Social work is deeply embedded in hegemonic practices, taken-for-grantedness, and everyday-life commonsense views. Therefore, it is even more important to reflect upon and constantly scrutinize this professional practice. Social work is to a great extent a normalizing practice (Payne, 2005; Payne, Adams, \& Dominelli, 2002). Social workers are not on a mission to change society and resist power structures; nevertheless they do have to confront and reflect upon these structures. Their profession is therefore stuck between upholding societal norms and practices and needing to confront and change some of these structures. Feminist and postcolonial critiques of social work have focused on the strong tendencies of essentialism and naturalism inherent in this clinical field of practice.

In this article we will investigate and explore the potential conflict between, on the one hand, social engineering and evidence-based social work, and on the other, critical social work. We will suggest an alternative way to approach and deal with social work practice and theory. Our ambition is not to criticize the ambition to base social work on more firm scientific grounds, but to present some thoughts and considerations on how to develop theoretical and scientific approaches to social work as a critical practice.

This article is mainly a theoretical work, and we will use examples and pertinent literature in order to develop our thoughts. The purpose is to present some ideas about how to theoretically position social work practice within a framework of critical theory. How can we combine the ambition to develop suitable methods and to anchor social work in a sound social-scientific context with critical theories of gender, ethnicity, and class? Our position is that it is important to use a constructivist, contextual and societal approach to enable these questions.

Often an evidence-based, social engineered social work and a critical stance are kept and described as separated because of their built-in differences. For instance the first approach often focuses on the individual and lacks knowledge about the context; it also addresses knowledge as something essential regarding how subjects "are". A critical approach on the other hand focuses on society and is based on contextawareness. The subject and society are seen as social, historical and cultural constructions (Herz \& Johansson, 2011). Our ambition is to get these different approaches to converge by contributing to a development of increased self-criticism and reflexivity in social work.

We will explore this in three sections. First we develop our critique of contemporary fallacies and problems in the theory and practice of social work, after which we present and discuss theories of 'doing' as used in relation to, for instance, gender, ethnicity, families, and class. Thereafter follows a section in which we explore the possibility of introducing the concept of doing into social work; and the final section is devoted to the conclusions to be drawn from this critical exploration and reflection. 


\section{FALLACIES IN SOCIAL WORK}

A strong tendency in contemporary social work is the movement towards a social practice based upon scientific evidence of what actually works. This has led to an increase of so-called evidence-based methods, systems, and manuals in social work practice (Blom, 2009). This development could be seen, to varying degrees, in countries like Sweden, Australia, England, Canada and in the USA (Gray, Plath \& Webb, 2009; Kufeldt, Vachon, Simard, Baker, \& Andrews, 2000; Wise, 2003). Criticism of this movement often concentrates on problems in measuring what really works. But some criticism has also been directed towards the neo-liberal individualization of 'social problems' that seems to follow upon the implementation of evidence-based practice (EBP) (Webb, 2001). Although it is by no means clear or uncontroversial what EBP is or how to interpret it (Morago, 2006; Payne, 2005), the requirement to implement EBP has in part had some real consequences. One such primary consequence is what could be called the increase of a manual-based social work. These manuals and systems are based on specific theoretical assumptions regarding both the individual and society (Garrett, 1999a, 1999b, 2002; Herz \& Johansson, 2011). The underlying theoretical assumptions are often barely mentioned and they are definitely not elaborated or visible in the different methods of measuring the effects of social work (Socialstyrelsen, 2006). In Britain the so-called Munro report, on behalf of the department for education, recently presented its final report. The report argues for a move away from these kinds of assessments often used as part of EBP. Instead it is a clear push towards the use of locally emerged knowledge and the social work expertise. Rather than using systems increasing rules, prescription, and bureaucratisation, Munro advocates social workers meeting with children and families, and the profession's own development of knowledge and skills (Munro, 2011). This critique and the upcoming work in Britain are interesting and might even lead towards a social work where parts of the problems we suggest here can be avoided. However, many systems, manuals, and methods are still in use, and the future social work implied in the report still needs to take these fallacies into account.

In social work, materials that are in use and are considered evidence-based often are based upon psychological or psychiatric knowledge. This tendency reflects a psychologization of society at large (Johansson, 2006, 2007, 2008; Rose, 1999). In itself this need not be a problem, but it does seem to shift the focus of social work more or less exclusively towards the level of the individual. 'Social problems' are seen as personal shortcomings and therefore as best addressed on an individual level. This eventually leads to other levels that affect different individuals' social lives, such as positional and structural levels, being diminished or even completely forgotten (Herz \& Johansson, 2011).

Social work has been criticized for strengthening a static, 'traditional', and sometimes even repressive view on positional power-asymmetries, such as for instance gender, sexuality, and ethnicity (Burck \& Gwyn, 1995; Dominelli, 2002, 2004, 2008; Sue, 2006). Others have criticized social work's lack of interest in the impact structural issues actually have on people's lives (Järvinen \& Mik-Meyer, 2003; Mik-Meyer, 2004). The implementations of EBP in social work risk further reinforcing this development. Many of the manuals and systems that are being used lack a critical view of positional factors and tend to ignore structural impact. Instead, evidence-based methods are supposed to work more or less regardless of the impact 
of structural circumstances (see Ward, 2000, on the supposed universality of the Looking After Children System, LACS, and the criticism by Garrett, 1999a, 1999b, 2002).

Social work is performing on the one hand moralizing work on the behalf of society, and on the other hand supportive work with individuals, groups, and on the societal level. Given this background it is hard or even impossible to ignore the demands for evidence-based social work, since one of its tasks is to present good results. But on the other hand, there is a risk that unwanted effects - such as strengthening gender-relations that do not mesh with gender-equal opportunity policies - will be reproduced. One such example is how gender is handled in the widely used system Looking After Children (LAC or sometimes LACS), in which it is stated that children need positive same-sex role-models to develop a positive identity (Horwath, 2000; Socialstyrelsen, 2006). This idea tends to strengthen rather static images of gender, and has been heavily criticized by feminist researchers (Hicks, 2006). It is important to remember that all knowledge is constructed in a political and historical context, and the systems, manuals, and tools used in social work are, of course, no exception (Nylund \& Nylund, 2003). The systems and manuals therefore contain theoretical assumptions about, for instance, gender, ethnicity, and other positional power asymmetries. This means that it is important to retain a critical stance in social work.

There is clearly a rift between on the one side more psychologically influenced and evidence-based social work and on the other side structural and critical social work. While structural social work obviously integrates a structural level into practical social work, and critical social work further includes a positional level, these levels are often lacking in more psychologically influenced social work. Social work faces the challenge of integrating, for instance, EBP-models with a more critical approach to different levels of analysis.

The literature in the field of social work sometimes approaches this gap between individually-oriented social work and critical social work. However, it is seldom properly analysed (Payne, 2005). Often the various different approaches to social work are presented and the reader is left with a simple choice of which theory or method to use in different situations. One way to begin loosening this tension could be to introduce the concept of 'doing' within social work. In the next section we will turn our attention to theories on doing gender, ethnicity, class, and families before returning to how this concept could be put to use in social work practice.

\section{DOING INSTEAD OF BEING}

The phrase 'doing gender' was originally coined in an article by Candace West and Don Zimmerman in the 1980s (West \& Zimmerman, 1987). Initially this term/concept was developed within the fields of symbolic interactionism and ethnomethodology. The term 'doing' conveyed the socially constructed nature of gender. Rather than viewing gender as something fixed, as being, gender and sexuality were seen as ongoing processes of doing. These authors, however, are still working within the paradigm of gender differences. There is a marked difference, for example, between West and Zimmerman's concept of doing and Judith Butler's concept of doing gender. In a recent article, West and Zimmerman (2009) comment upon the historical development of the concept. Although they celebrate its manifold 
uses and elaborations within feminist theory, they also reaffirm that gender cannot be totally undone, with reference to Judith Butler's use of undoing gender, though it can be redone. The structures responsible for upholding a specific way of doing gender cannot be fully eradicated, but it is possible to develop less oppressive ways of doing gender (Connell, 2010). When Butler talks about undoing gender she talks about a rearticulation of gender as something new that includes groups of people previously excluded from normative assumptions of gender (Butler, 2004). The main difference between the two seems to lie in to which degree how we do gender could change.

Reading the literature on 'doing gender' is actually quite confusing. An entire issue of Gender \& Society was recently devoted to the concept of 'doing' (Messerschmidt, 2009). In fact, many nuances and versions of the concept and its application are used in gender studies. Sometimes it is used to designate quite stable processes of 'doing' gender, and at other times we find it twisted to denote a more radical transformation, with both 'undoing' and 'redoing' of gender. In short, our take on 'doing' is that these kinds of tools and concepts make it possible to focus on processes and on the ongoing construction of gender. It is, of course, possible to similarly speak of 'doing family' or 'doing class', for instance. The charm of the concept mainly lies in its ability to capture movement, processes, and the flavour of transformations in everyday life. When using the concept of doing, we also get closer to the actual processes going on in families and the intimate sphere of everyday life.

Before returning to the question of the connection between the concept of doing and social work, we will introduce a possible model and way of discussing and analysing processes of doing at different levels. We will use the concept in a much wider sense than is the case in gender theory. Doing will here be a part of different processes of constructing and doing gender, class, ethnicity, family, and so on. This makes it possible to understand doing as vertically differentiated; in other words, doing must be understood as something layered and comprising different analytical levels. Of course, these levels influence and affect each other. Moreover, doing also has to be understood as differentiated horizontally with different positions being made differently. Finally, doing takes place within a framework consisting of everyday reflexivity.

Some appraisals of the concept of 'doing', however, have viewed it as neglecting structural injustice. Fraser (2007) for instance, points out the importance of a 'twodimensional approach to gender justice'. By that she means that one cannot merely focus on recognition (i.e. identity politics) without also theorizing distribution (i.e. differentiated status based on gender). We consider it important to take both dimensions into account simultaneously - to pay attention to structural injustice at the same time as you pay attention to the subject standing in front of you - but without needing to assume that either of these two levels is the determinant. Both structural as well as individual gender relations are still being made and are constantly a part of 'doing', though sometimes in different ways. They both have to be analysed like this in order not to risk strengthening and reproducing undesired power-relations and positions. Our model of 'doing' therefore takes both levels into account.

Vertically, the concept of doing is understood through different analytical levels (see Figure 1). At a cultural level, doing will be expressed in the form of language games (Wittgenstein, 1953/1973). The identity process will be constituted by these language games, and by the naming of different social and cultural phenomena. 
Through language, and in a performative fashion, sexuality, gender, and identity are constructed. Bodies are not merely described - in language and by naming - they are also constituted and constructed (Butler, 1990, 2004). At a social level, doing is expressed as social interaction. When we meet people face-to-face, we also become part of a social game in which bodies, movements, and contact between different people lead to certain scenarios. At this level, identity takes the form of different rituals (Collins, 1997). These rituals are, of course, also constituted and developed in language games, but they are also social in the sense of being a rudimentary form of social exchange preceding the creation of groups, organizations, and institutional settings. Finally, we also have physical aspects of doing. Doing, to a great extent, is also a bodily phenomenon. Through movements in space, clashes between bodies, and the identity process of embodiment, practices are also very physical and concrete (Ahmed, 2004, 2007). These three different levels certainly interact and make up complex patterns of doing.

\section{Figure 1: Different Levels of 'Doing'}

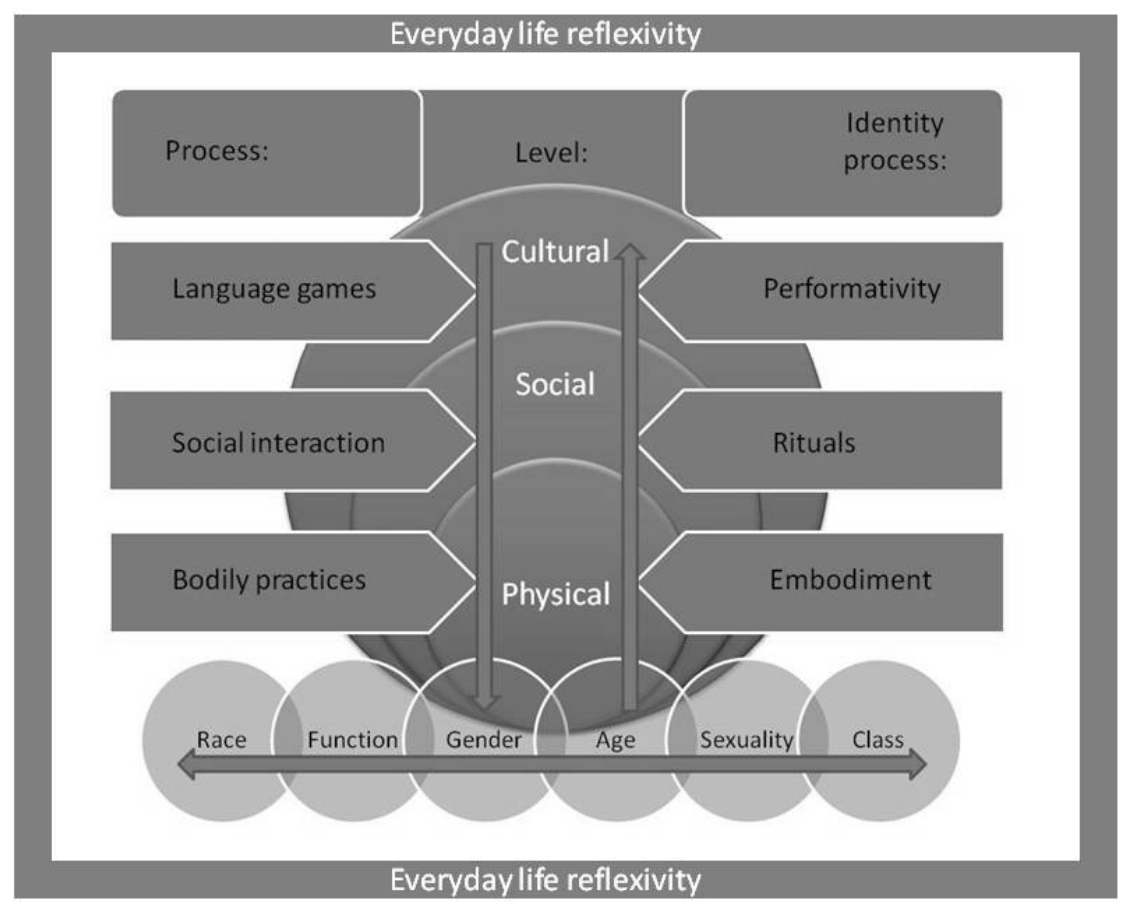

However, different positions are being done differently. This means that apart from understanding the different levels of doing, we also have to understand and know about the different power-relations connected to positions, such as gender, class, ethnicity, race, or sexuality. The reason is that different positions are constructed, staged, and embodied differently. Gender, and more importantly differences based upon gender (such as femininity and masculinity), are in many ways connected to bodily differences, as might not be the case with sexuality, for instance. When walking through town, the act of doing difference based on gender 
may more easily crystallize through practices and embodiments such as style, clothes, or hair. Doing differences based on sexuality could manifest itself in another way. A form to be filled out at the local social services office that is marked 'the man's signature' and 'the woman's signature' could instead point at sexuality, and not first and foremost at gender, although they are of course interrelated.

Differences and power-asymmetries based on race are also done differently than those based on class, for example (Mattsson, 2010). In addition, this means that we might need different theories to understand and be able to analyse different positions. To be able to understand gender we need to turn to feminist research and theories on 'doing gender'; to comprehend ethnicity and race, we might have to go to postcolonial research and its attendant theories. This should not be read as meaning that doing gender is completely separated from doing ethnicity, family, or sexuality. On the contrary, positions are intersectionally connected to each other, interrelate with each other, and could both strengthen certain patterns as well as eclipse each other (Crenshaw, 1989, 1991; Staunæs, 2003; Yuval-Davies, 2007). For instance, gender and race could reinforce certain power-relations and thereby, for example, affect black women's lives and opportunities in a specific way (Hill Collins, 1998), while in other situations one position could be given more importance than the other.

The reason for distinguishing between different levels of doing is first and foremost to put the concept in relation to different theories of the construction of identity and practices. In doing this, we will promote a multilayered understanding of doing social work. This will help us to discern and analyse different aspects of social practices and attempts to intervene in social life. The reason for bringing doing into social work practices is that this will lead to better and richer analyses of the complex work being done. Doing is a part of everyday life reflexivity, and thus instead of locking ourselves into a certain understanding of situations, people, and 'social problems', we will be able to set social reality and social practices in motion. By implementing this perspective on doing, we will also find better ways of dealing with 'social problems'. Social problems are not stable phenomena, but instead are defined, constructed, and named. What we are dealing with, briefly stated, are social processes of doing social work.

\section{DOING SOCIAL WORK}

Social worker 1: He’s a boy, for starters.

Boss: $\mathrm{mmm}$

Social worker 1: Everyone knows about the case, right? We don't have to say too much about their background. So, where should we start?

Social worker 2: Alright, risk-factors... on an individual level. Ok, he is a boy. Actually we don't know that much more about him.

Social worker 1: He's been a problem at school.

Social worker 2: Mmm. He has difficulties at school.

Social worker 1: That was improving, just before his mom passed away, but now... we don't know

Social worker 2: Is it that he's having difficulties learning, and such? 
Social worker 1: Not that we... No, he hasn't had any problems relating to people and stuff like that

Boss: Easy relating to people, does that mean he is a nice boy?

Social worker 1: He is a bit of a tough kid. Well, he looks trendy and is most likely good-looking in the eyes of his girl peers. Or, well, you might say [...] It depends on who's looking at him, because an older person might think he's a brash, cool guy, you know, with a cap sidewise with some brand-name on it and a hoodie. So I don't know, you might.

This conversation took place at a social services office during a meeting about a young boy under consideration for an intervention by the social services. ${ }^{i}$ The quote shows how different positions interrelate and are used by the social workers to make an assessment in the case. At this meeting, the social workers used two different but compatible evidence-based systems, BBIC ('Barns Behov i Centrum', the Swedish version of the British 'Looking After Children System', LACS) and Ester. Ester is a system for assessing young people's risk of developing antisocial behaviour (Andershed \& Andershed, 2010). We will not dwell on the systems themselves, but rather point out some interesting statements and conceptions they are based on. After doing this we will suggest how the concept of 'doing social work' could be of help in avoiding some of the pitfalls an uncritical and unreflexive approach to positional power-asymmetries might entail.

First of all, gender is being highlighted. The fact that, biologically, the client is a young male is made important and is treated as synonymous with being at risk. When the social worker stresses that the client is a boy, this is noted on a whiteboard by the supervisor under the heading of 'risk'. One reason why the social workers put so much emphasis on this is that the assessment-system Ester states that boys are more likely to be exposed to and get involved with antisocial behaviour (Andershed \& Andershed, 2010). Even if this may be statistically valid in general, on an individual level the social workers' assessments and decisions based on this assumption might lead to these constructions of masculinity being constantly reproduced. For example, boys in Sweden receive treatment and other interventions to a greater extent than girls (Brunnberg, 2002). An assumption of risk based solely on gender might cause this imbalance to continue or even grow.

Later in the conversation, another aspect of different power relations based on positions is brought up. First they say the boy is good looking in the eyes of female peers. This is a heteronormative assumption, based on the conception that attraction solely occurs between men and women (Butler, 2004). The boy is considered beautiful in the eyes of girls, not other boys. But then something further happens, when the social worker adds age as a factor. Now, the boy might not be seen as beautiful anymore, but instead as arrogant, cool, and maybe a bit cocky. Here the combination of different positions creates different assessments. One possible reason why appearance is given so much attention in the discussion could be because it is stressed as an important factor in both the Swedish BBIC and the British LACS, for instance regarding clients' awareness of how other people might perceive their looks (Department of Health, 2000).

The above example shows us how different positions, such as age and gender, might be used and interpreted differently. The manuals and systems used for the 
assessments provide the social workers with statistical information and point them in certain directions regarding questions to ask and possible outcomes. By doing so, and by not going any further than this point they might lead to certain notions of, in this case, gender and age being reproduced. For instance, the belief that boys, because of their biological self, need more support to avoid developing anti-social behaviour might in itself lead to an increase in statistics on boys coming to the attention of the social services. Therefore, social work needs to develop a more dynamic view of gender, race, ethnicity, sexuality, and other positions.

When engaging in 'doing social work', these above-mentioned assumptions must therefore be put into context and analysed as being parts of constructions on different levels; and most importantly, as being precisely that: constructions. What on one level seems to be clear, could under the influence of another be understood as exactly the opposite, or rather, as something complex and fluid.

We will suggest that social work needs to turn towards a view of theory and practice as being part of everyday reflexivity. Instead of relying heavily on psychological conceptions and stable notions of personality/identity, we would like to see a movement in the direction of processes and reflexivity. By introducing the concept of doing social work, we aim to promote changes in how social workers approach, evaluate, and assess 'social problems'. Instead of taken-for-granted social appearances and behaviors, we propose that social workers use a process perspective, and focus on bodily practices, social interaction, and language games.

While race, gender, age, sexuality, and class, for example, are often treated as stable categories, almost as parts of a personality, we suggest that these 'categories' are constantly evaluated, deconstructed, and put into motion. Doing social work would then be a demanding social practice, with critical and ongoing discussions about changes at the physical, social, and cultural levels as an important tool and practice. Through questions such as: 'What does gender mean here?' 'What is a modern family?' and 'What does cultural difference mean?', we could set social work in motion.

This means that social work needs to develop a practice in which critical evaluations are a part of everyday social work. By raising reflexive questions on the meaning of positions such as gender, and actively relating to different notions of these positions, social work could avoid static assumptions that can lead to an unreflective reproduction of positions. When analysing and questioning different approaches to, for instance, 'doing family', and putting this into the context of the current client's life, it is possible to both acknowledge differences on a structural level and differences in people's approaches to these discourses.

By doing this it is also possible to avoid the trap pointed out by Fraser (2007) above: to either presume that people unreflectively live their lives in conformity with structural elements; or to do the opposite: to believe that people can live their lives free from the influence of the same elements. Instead, our concept of 'doing social work' makes possible a reflexive analysis of how the client, under the influence of different levels, does gender, for instance.

Doing social work means being in constant contact with everyday reflexivity, and being prepared to engage in critical discussions on processes. This would be a vital 
and highly relevant alternative to the sometimes careless use of categories and the problems of reification that trouble the profession.

What we are suggesting is a development towards a meta-reflexive way of thinking, where social workers put their own practice under the microscope. Categories of differences and power-asymmetries have to be understood theoretically through different analytical levels, not as static notions. Gender could for instance be given different significance depending on which level; bodily, societal or cultural, and how it is being related to other categories. Through the use of a meta-reflexive approach, social work might be able to set static notions in motion, towards a social work more sensitive towards changes and differences.

\section{CONCLUSIONS}

Our ambition has been to identify, investigate, and explore some dubious developments within social work. We also had the purpose to suggest and develop a method to use for a reflexive approach to practice. Our center of attention has therefore been on the social workers themselves, suggesting the development of a meta-reflexive approach. This, of course, does not mean that our proposal in extension cannot get clients to benefit as well.

The critique thus serves as a starting point for the development of a reflexive mode of thinking about and relating to social work practice. In order to counteract tendencies towards individualization, fragmentation, and psychologization - however weak or strong these are in different settings - we have introduced the concept of doing social work. Instead of locking social workers into certain conceptual frameworks and notions of being a social worker, we suggest a movement towards a more deconstructive and reflexive mode of thinking and performing social work. Further we also suggest that this way of reflexive thinking and performing also could be employed by social workers who already make use of postmodern and critical approaches. This could somewhat be seen as a way of work compatible with the results from the British Munro-report, changing focus from "a compliance to a learning culture” (Munro, 2011, p. 129).

Contemporary social work faces a number of challenges, the first of which being the above-mentioned criticism that it strengthens specific hegemonic notions of positions, for instance gender. Another is the implementation of evidence-based social work, which presents new challenges like the requirement of measurability and the sometimes static positions that may be adopted to meet this requirement. These parallel developments increase the importance of developing a form of social work that does not rely on imaginative or common assumptions regarding people's identities and lives. Instead of locking people into static positions and closed identities, 'doing social work' makes it possible to develop a truly ethical and reflexive position and a new professional identity.

Another challenge for contemporary social work is to meet the demands of a more solid scientific practice. However, it is equally important that social work find ways of keeping an ongoing critical discussion alive, on what evidence is and what effects it can have. The question is how to combine the ambition to anchor social work in this sound scientific context with critical theories concerning, for instance, gender, ethnicity, and class. We suggest that a movement towards a more 
deconstructive and reflexive mode of thinking and practising social work, 'doing social work', would enable the field to become more ethical and reflexive.

\section{References}

Ahmed, S. (2004). Collective feelings: Or, the impressions left by others. Theory, Culture \& Society, 21(2), 25-42.

Ahmed, S. (2007). A phenomenology of whiteness. Feminist Theory, 8(2), 149-68.

Andershed, H., \& Andershed, A-K. (2010). Risk-need assessment for youth with or at risk for conduct problems: Introducing the computerized assessment system ESTER. Procedia Social and Behavioral Sciences, 5, 377-383.

Blom, B. (2009). Knowing or un-knowing? That is the question: In the era of evidence-based social work practice. Journal of Social Work, 9(2), 158-177.

Brunnberg, E. (2002). Are boys and girls treated in the same way by the Social Services? In C. Gruber \& H. Stefanov (Eds.), Gender in social work. Promoting equality (pp. 119-131). Dorset: Russell House Publishing Ltd.

Burck, C., \& Gwyn, D. (1995). Gender and family therapy. London: Karnac Books.

Butler, J. (1990). Gender trouble: Feminism and the subversion of identity. London: Routledge.

Butler, J. (2004). Undoing gender. London: Routledge.

Collins, R. (1997). Interaction ritual chains. Princeton, NJ: Princeton University Press.

Connell, C. (2010). Doing, undoing, or redoing gender? Learning from the workplace experiences of transpeople. Gender \& Society, 24(1), 31-55.

Crenshaw, K. (1989). Demarginalizing the intersection of race and sex: A black feminist critique of antidiscrimination doctrine, feminist theory and antiracist politics. In K. D. Weisberg (Ed.). Feminist legal theory: Foundations (pp. 57-80). Philadelphia: Temple University Press.

Crenshaw, K. (1991). Mapping the margins: Intersectionality, identity politics, and violence against women of color. Stanford Law Review, 43(6), 1241-1299.

Department of Health. (2000). Framework for the assessment of children in need and their families. London: HMSD

Dominelli, L. (2002). Feminist social work theory and practice. Basingstoke: Palgrave Macmillan.

Dominelli, L. (2004). Social work: Theory and practice for a changing profession. Cambridge: Polity Press.

Dominelli, L. (2008). Anti-racist social work. Basingstoke: Palgrave Macmillan.

Englar-Carlson, M., \& Shepard, D. S. (2005). Engaging men in couples counseling: Strategies for overcoming ambivalence and inexpressiveness. The Family Journal: Counselling and Therapy for Couples and Families, 13(4), 383-391.

Fook, J. (2002). Social work: Critical theory and practice. London: Sage. 
Fook, J., \& Gardner, F. (2007). Practising critical reflection: A resource handbook. Maidenhead: Open University Press.

Fraser, N. (2007). Feminist politics in the age of recognition: A two-dimensional approach to gender justice. Studies in Social Justice, 1(1), 23-35.

Garrett, P. M. (1999a). Mapping child-care social work in the final years of the twentieth century: A critical response to the "Looking After Children" system. British Journal of Social Work, 29, 27-47.

Garrett, P. M. (1999b). Producing the moral citizen: The "Looking After Children” system and the regulation of the children and young people in public care. Critical Social Policy, 19(3), 291-311.

Garrett, P. M. (2002). Yes Minister: Reviewing the "Looking After Children” experience and identifying the messages for social work research. British Journal of Social Work, 32, 831-846.

Gray, M., Plath, D., \& Webb, S. A. (2009). Evidence-based social work: A critical stance. New York: Routledge.

Herz, M., \& Johansson, T. (2011). Critical social work - Considerations and suggestions. Critical Social Work, 12(1), 28-45.

Hicks, S. (2008). Gender role models... who needs 'em?!. Qualitative Social Work, $7(1), 42-59$.

Hill Collins, P. (1998). It's all in the family: Intersections of gender, race and nation. Hypatia, 13(3), 62-82.

Horwarth, J. (2000). Child's world: Assessing children in need. London: Jessica Kingsley Publishers.

Johansson, T. (2006). Makeovermani: om Dr. Phil, plastikkirurgi och illusionen om det perfekta jaget. Stockholm: Natur \& Kultur.

Johansson, T. (2007). Experthysteri: Kompetenta barn, curlingföräldrar och supernannies. Stockholm: Atlas.

Johansson, T. (2008). Managementsyndromet: Så skapas den moderna chefen. Stockholm: Atlas.

Järvinen, M., \& Mik-Meyer, N. (2003). At skabe en klient : institutionelle identiteter i socialt arbejde. København: Hans Reitzel.

Kufeldt, K., Vachon, J., Simard, M., Baker, J., \& Andrews, T. L. (2000). Looking After Children in Canada: Final report. Retrieved from http://www.unb.ca/fredericton/arts/centres/mmfc/ resources/pdfs/team2000a.pdf

Marcuse, H. (1964). One-dimensional man. Studies in the ideology of advanced industrial society. Boston: Beacon Press.

Mattsson, T. (2010). Intersektionalitet i socialt arbete. Teori, reflektioner och praxis. Malmö: Gleerups.

Messerschmidt, J. W. (2009). "Doing gender”. The impact and future of a salient sociological concept. Gender \& Society, 23(1), 85-88. 
Mik-Meyer, N. (2004). Dømt til personlig udvikling: identitetsarbejde i revalidering. København: Hans Reitzel.

Morago, P. (2006). Evidence-based practice: From medicine to social work. European Journal of Social Work, 9(4), 461-477.

Munro, E. (2011). The Munro review of child protection: Final report. A childcentred system. London: Department for Education.

Nylund, D., \& Nylund, D. A. (2003). Narrative therapy as a counter-hegemonic practice. Men and Masculinities, 5(4), 386-394.

Payne, M. (2005). Modern social work theory ( $3^{\text {rd }}$ ed.). New York: Palgrave Macmillan.

Payne, M., Adams, R., \& Dominelli, L. (2002). On being critical in social work. In R. Adams, L. Dominelli, \& M. Payne (Eds.), Critical practice in social work (pp. 112). New York: Palgrave.

Pease, B., \& Fook, J. (1999). Transforming social work practice: Postmodern critical perspectives. London: Routledge.

Rose, N. (1999). Governing the soul: The shaping of the private self $\left(2^{\text {nd }}\right.$ ed.). London: Free Association Books.

Socialstyrelsen. (2006). Grundbok barns behov i centrum BBIC. Stockholm, Socialstyrelsen.

Staunæs, D. (2003). Where have all the subjects gone? Bringing together the concepts of intersectionality and subjectification. NORA, 11(2), 101-110.

Sue, D. W. (2006). Multicultural social work practice. Hoboken, NJ: John Wiley \& Sons.

Ward, H. (2000). The developmental needs of children: Implications for assessment. In J. Horwath (Ed.), The child's world: The comprehensive guide to assessing children in need (pp. 167-179). London: NSPCC and the University of Sheffield.

Webb, S. A. (2001). Some considerations on the validity of evidence-based practice in social work. British Journal of Social Work, 31(1), 57-79.

West, C., \& Zimmerman, D. H. (1987). Doing gender. Gender \& Society, 1(2), 12551.

West, C., \& Zimmerman, D. H. (2009). Accounting for doing gender. Gender \& Society, 23(1), 112-22.

White, M. (2004). Folk psychology and narrative practices. In L. Angus \& J. McLeod (Eds.), The handbook of narrative and psychotherapy: Practice, theory, and research (pp. 15-51). Thousand Oaks, CA: Sage Publications.

Wise, S. (2003). An evaluation of a trial of Looking After Children in the state of Victoria, Australia. Children \& Society, 17, 3-17.

Wittgenstein, L. (1953/1973). Filosofiska undersökningar. Stockholm: Bonnier. 
Yuval-Davies, N. (2007). Intersectionality, citizenship and contemporary politics of belonging. Critical Review of International Social and Political Philosophy, 10(4), 561-574.

Author note:

Address correspondence to: Marcus Herz, Department for Law, Psychology, and Social Work at Örebro University, Sweden. Email: marcus.herz@oru.se

\footnotetext{
' The quote is taken from one of the authors' ongoing $\mathrm{PhD}$-thesis on how gender and ethnicity are made, used, and understood in social work. This specific quote was collected during an ethnographic study conducted in 2010 at a meeting with a group of social workers responsible for conducting investigations in a municipality in Sweden. The use of the BBIC-system (equivalent to the British LAC System) is common in Sweden, and the state supports the implementation (www.socialstyrelsen.se). The Estersystem, however, is relatively new, but the number of municipalities using it is steadily increasing (www.ester-bedomning.se).
} 